\title{
Interfaces of Student Lifestyle and Perceived Stress
}

\author{
Daiva Vizbaraitė ${ }^{1}$, Gintarė Stanionytė ${ }^{1}$, Zbigniew Ossowsky ${ }^{2}$ \\ Lithuanian Sports University ${ }^{1}$, Kaunas, Lithuania \\ Gdansk University of Physical Education and Sport ${ }^{2}$, Gdansk, Poland
}

\begin{abstract}
Background. It is becoming obvious that healthy lifestyle of students in higher education institutions is an important factor contributing to the duration of their professional career as well as for general health (Bolotin \& Bakayev, 2015). High academic expectations increase tension and pose a threat to physical and mental health of students (Shamsuddin et al., 2013). During studies young people are more vulnerable to developing harmful habits, they do not follow proper nutrition, and do not look after their health (Tarejeva, Žagminas, \& Serapinas, 2015), therefore, it is important to understand the association between lifestyle of a young person and daily perceived stress.

Methods. The study included 155 students of the Lithuanian Sports University. In order to establish nutrition and harmful habits among students, the analysis of nutrition and harmful habits questionnaire was used. Physical activity of students was evaluated using the short version of the International Physical Activity Questionnaire (IPAQ-LT). The analysis of stress was based on the questionnaire using the Stress in Academic Life Scale. The results were processed using methods of mathematical statistics. The statistical analysis of the data was performed using the SPSS software version 23.0.

Results. Statistically significant difference of physical activity was determined between genders - females were more active than males $(p<.05)$. The frequency of the consumption of breakfast, sweets, meat, beer, and wine statistically significantly differed between females and males $(\mathrm{p}<.05)$. Perceived stress of students was associated with physical activity, consumption of cereal grains, sweets, carbonated beverages, and smoking $(p<.05)$.

Conclusions. The majority of students were sufficiently physically active. Females more frequently had breakfast, consumed sweets, while males more frequently consumed meat. Regular breakfast consumption was reported by $88.6 \%$ of females and $73.1 \%$ of males. Males more frequently had intake of beer, while females - wine. Significant relationship between perceived stress and physical activity among students was determined in the study.
\end{abstract}

Keywords: students, stress, nutrition, physical activity, harmful habits.

\section{INTRODUCTION}

$\mathrm{A}$ cademic studies are a remarkable time in life of every young person, and are associated with new experiences, academic-related challenges, living away from family. It is a period of the successful beginning of a new life; however, for others, this time poses a challenge of coping with academic pressure or perceived stress (Stoliker \& Lafreniere, 2015). Prolonged exposure to perceived stress may have a negative impact on academic achievements and health of a student (Lin \& Huang, 2014). According to data of studies, students who are incapable of coping with academic pressure and are affected by negative events may be exposed to symptoms of depression or even suicidal thoughts (Rosiek, Rosiek-Kryszewska, Leksowski, \& Leksowski, 2016).

It has been known that improper nutrition may have a negative effect on academic success of students, and poor eating habits may contribute to such health problems as diabetes mellitus, hypertension or different types of cancer (Brown, O'Connor, \& Savaiano, 2014). There is a number of studies indicating that Lithuanian students do not have proper nutrition habits (Proškuvienė \& 
Česnavičienė, 2015; Merkys, Norkus, \& Dovydaitis, 2016), and the consumption of unhealthy foods prevails among students of higher education institutions (Žandaras \& Stukas, 2015).

Intensive physical activity and socialization appear to be beneficial in both reducing poor mental health and perceived stress among students (VanKim \& Nelson, 2013). However, studies performed in Lithuania and foreign countries have shown that physical activity is insufficient among students of higher education institutions, and have displayed a clear tendency to decline (Kardelis \& Kardeliene, 2013; Plotnikoff et al., 2015).

Despite the negative effect on health, psychoactive substance abuse, particularly among young people, is common worldwide (Arora et al., 2016). Studies, financial situation, smoking, narcotic substances and alcohol consumption have been identified as the main risk factors of perceived stress among students (Melaku, Mossie, \& Negash, 2015).

Although quite a few studies on nutrition habits, physical activity, and the use of psychoactive substances among students are performed, the data between the interrelationship of these factors and perceived stress among students in Lithuania are not broadly analysed. Therefore, it is important to understand how lifestyle habits are associated with perceived stress in daily life among students. The study is based on the following questions: what are the peculiarities of physical activity, nutrition and harmful habits of students, and how they are associated with perceived stress? The aim of the study was to determine the peculiarities of physical activity, nutrition, and harmful habits among students, and the association of these factors with perceived stress. The object of the study was the association between perceived stress, physical activity, nutrition and harmful habits among students of the Lithuanian Sport University.

\section{METHODS}

A questionnaire-based survey. Physical activity of students was evaluated using the short version of the International Physical Activity Questionnaire (IPAQ-LT). The analysis of responses was based on the recommendations of the IPAQ scientific committee: the Metabolic Equivalent Task (MET) was used for recoding the intensity of physical activity. Nutrition habits and the frequency of harmful habits were determined using the methods of health behaviour of Lithuanian adolescents and adults (Grabauskas, Zaborskis, Klumbienè, Petkevičienè, \& Žemaitienè, 2004). The content of the questionnaire of nutrition habits included items of different foods and could be answered on an 8-point scale (from 1 to 8). The analysis of habits of alcohol consumption was based on students' responses about consumption of strong alcohol beverages, beer and wine. To determine smoking habits, students had to answer the question "Do you smoke"? Perceived stress was evaluated using the Stress in Academic Life Scale (SALS) by Konduri, Gupchup, Borrego, \& WorleyLouis (2006). SALS included 27 items where the responses were made on a 4-point scale (1 - "Not stressful or does not exist", 2 - "Little stressful", 3 - "Moderately stressful", and 4 - "Severely stressful".

Statistical analysis. The statistical analysis of the data was performed using the SPSS software version 23.0. Arithmetic means and mean standard deviations of the analysed parameters (age, height, weight) were calculated using the mathematical methods of statistics. A relationship between categorical variables was determined by chi-square $\left(\chi^{2}\right)$ criteria. Spearman's correlation coefficient was used to analyse a relationship between variables. Significance level was set at $p<.05$.

\section{RESULTS}

The results of the study revealed the moderate level of physical activity in the majority of females $(81.8 \%)$ and males (65.7\%) (Figure 1). The study determined that more males (19.4\%) than females $(15.9 \%)$ had insufficient physical activity. The difference of the results was statistically significant considering genders $(p<.05)$.

The study determined that the majority of students $(88.6 \%$ of females and $73.1 \%$ of males) tended to have breakfast. Breakfast skipping was reported only by $3.4 \%$ of females and $11.9 \%$ of males. The difference of the results was statistically significant $(p<.05)$.

The results of the study demonstrated that $44.3 \%$ of females and $67.2 \%$ of males consumed meat 5-7 times per week (Figure 3). Meat consumption 1-4 times per week was pointed out by $47.7 \%$ of females and $28.4 \%$ of males. The results between genders were statistically significant $(p<.05)$.

The results showed that the majority of females $(83.0 \%)$ and males $(80.6 \%)$ reported having fruit 
Figure 1. Physical activity

Notes. $\chi^{2}=9.46, d f=2, p=.01$.



Figure 2. Breakfast consumption

Notes. $\chi^{2}=6.70, d f=2, p=.04$.

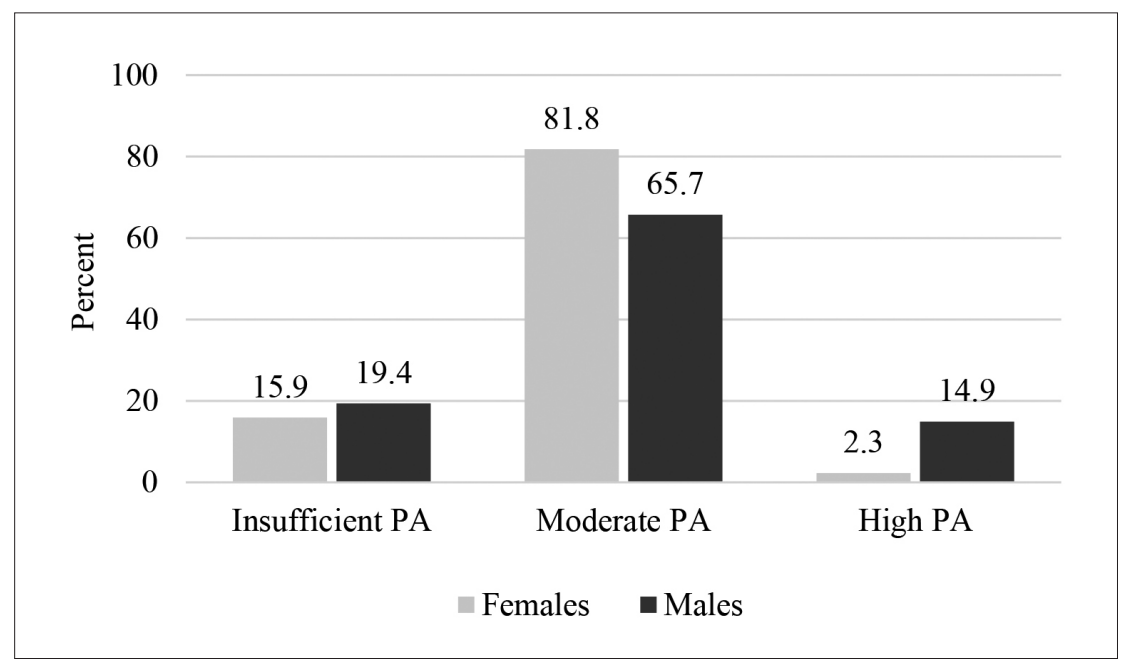

Figure 3. Meat consumption

Notes. $\chi^{2}=8.00, d f=2, p=.02$.

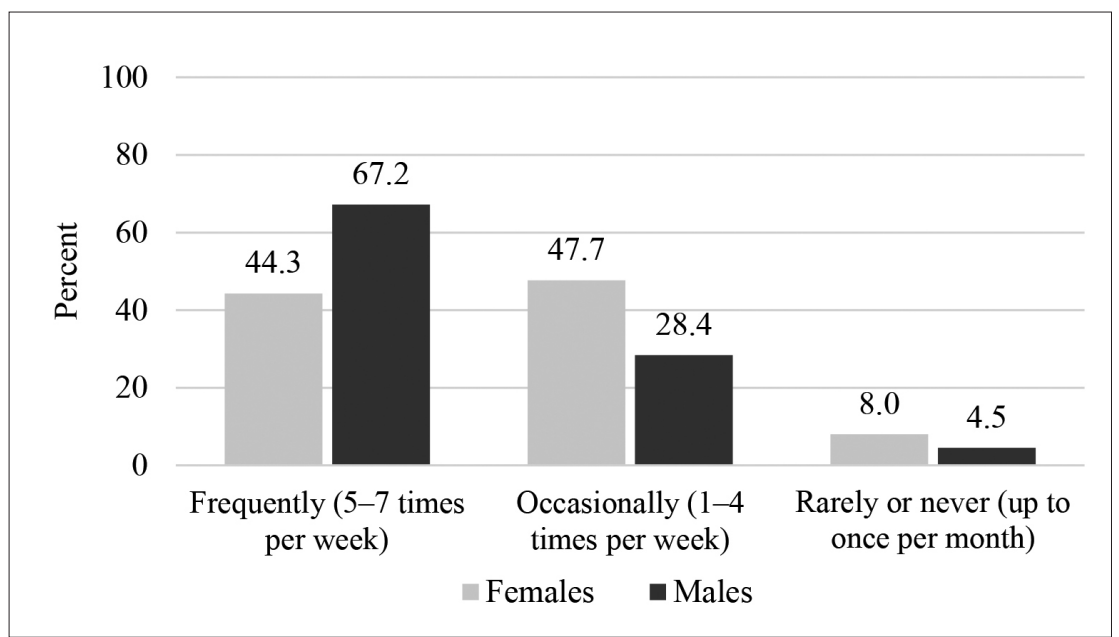

and vegetables up to 4 times per week (Figure 4). Frequently (5-7 times per week) fruit and vegetables were consumed only by $8.0 \%$ of females and $4.5 \%$ of males. Statistically significant results were not found $(p>.05)$.
The results of the study showed that frequent intake of sweet food was reported by $27.3 \%$ of females and $7.5 \%$ of males (Figure 5 ). The majority of students (47.7\% of females and $59.7 \%$ of males) had intake of sweet foods from 1 to 4 times per 
week. The difference of the results was statistically significant $(p<.05)$.

In response to tobacco use, $14.8 \%$ of females and $19.4 \%$ of males reported a daily use of tobacco (Figure 6). Occasional use of tobacco was indicated by $12.5 \%$ of females and $6.0 \%$ of males.
Non-smoking was reported by $72.7 \%$ of females and $74.6 \%$ of males. Statistically significant differences in results between genders were not found $(p>.05)$.

A comparison of beer consumption between both genders showed that $23.9 \%$ of males used beer 2-3 times per week, while the majority of females

Figure 4. Fruit and vegetable consumption

Notes. $\chi^{2}=1.85, d f=2, p=.39$.

Figure 5. Sweet food consumption

Notes. $\chi^{2}=9.83, d f=2, p=.01$.

Figure 6. Distribution of smoking in students

Notes. $\chi^{2}=2.8, d f=2, p=.34$
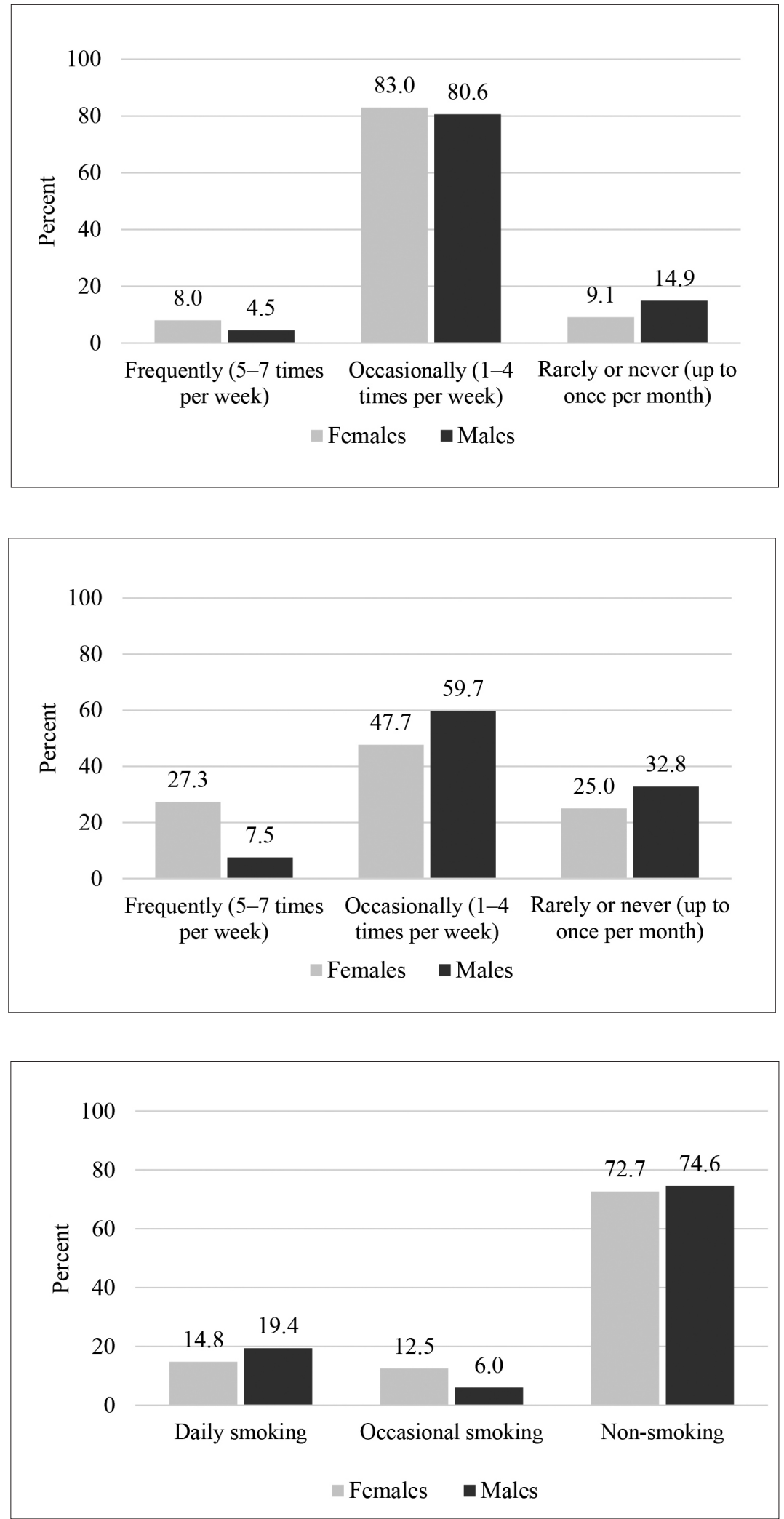
(35.2\%) consumed beer 2-3 times per month (Figure 7). The results indicated that $17.0 \%$ of females and $25.4 \%$ of males did not consume beer at all. The differences in results between genders were statistically significant $(p<.05)$.

In response to the frequency of wine consumption, the majority of males (43.3\%) reported not using wine, while only $17.0 \%$ of females stated that they did not consume wine (Figure 8). More frequent wine consumption was reported by females: $2-3$ times per month by $33.0 \%$ of females and $11.9 \%$ of males, once per week $5.7 \%$ of females and $3.0 \%$ of males. The results were statistically significant $(p<.05)$.
Figure 7. Frequency of beer consumption

Notes. $\chi^{2}=20.12, d f=4, p=.01$.

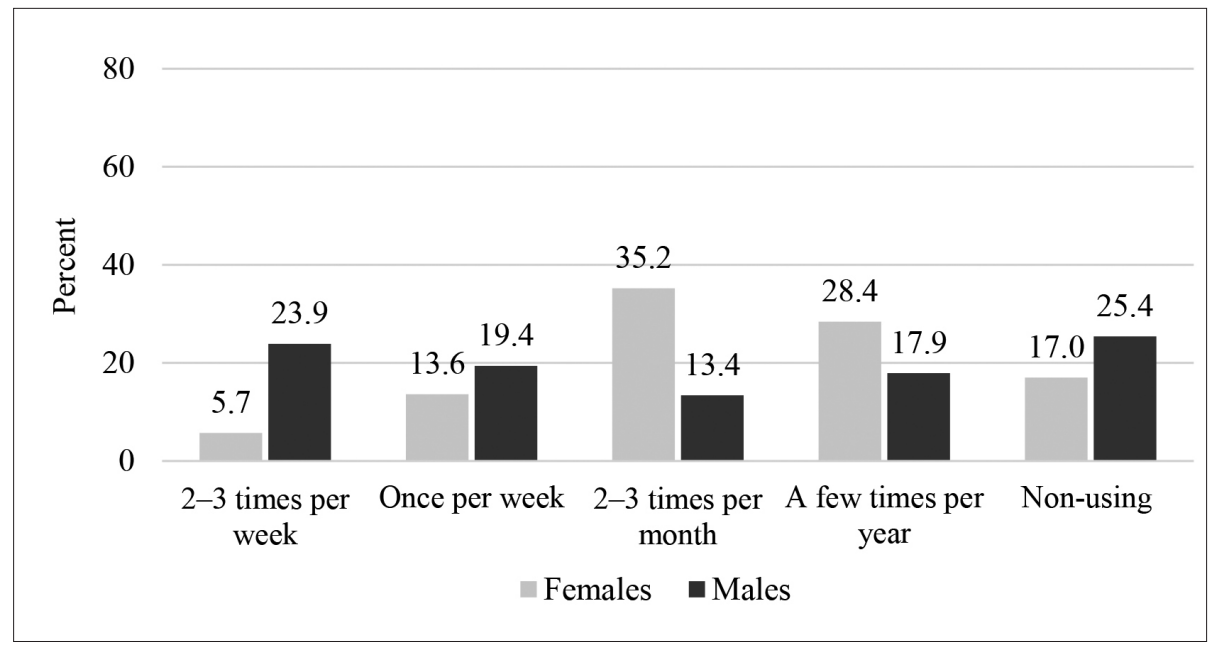

Figure 8 . Frequency of wine consumption

Notes. $\chi^{2}=18.39, d f=4, p=.01$.

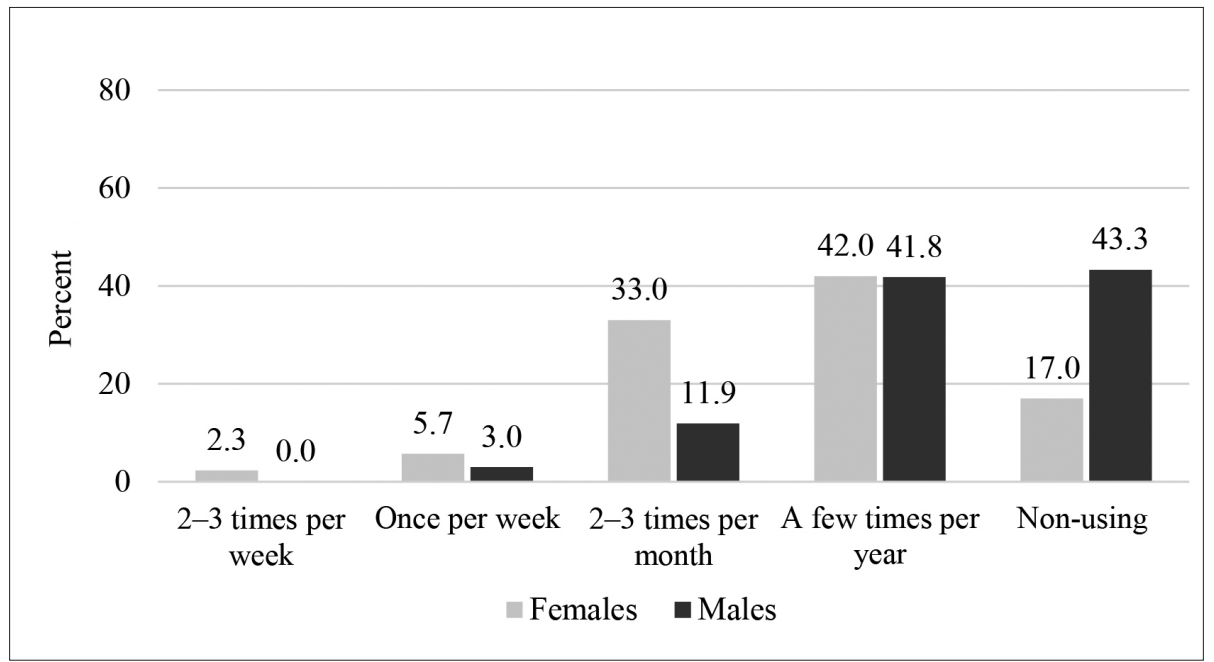

The results presented in Table 1 revealed that physical activity was statistically significantly associated with perceived stress among students

Table 1. Interrelationship between perceived stress and physical activity among students

\begin{tabular}{|c|c|c|c|c|}
\hline \multirow{2}{*}{} & \multicolumn{3}{|c|}{ Stress } \\
\cline { 2 - 5 } & \multicolumn{2}{|c|}{ Females } & \multicolumn{2}{c|}{ Males } \\
\cline { 2 - 5 } & $\begin{array}{c}\text { Correlation } \\
\text { coefficient }\end{array}$ & $p$ value & $\begin{array}{c}\text { Correlation } \\
\text { coefficient }\end{array}$ & $p$ value \\
\hline $\begin{array}{c}\text { Physical } \\
\text { activity }\end{array}$ & $-.344 * *$ & .001 & $-.514 * *$ & .001 \\
\hline
\end{tabular}

Note. $* * \mathrm{p}<.01$. $(p<.05)$. The analysis of the results showed that physical activity was associated with perceived stress in both samples of the studied, and the interrelationship was found to be inverted - the more students were physically active, the lower level of stress they perceived.

While searching for the association between nutrition habits and stress (Table 2), it was determined that stress was statistically significantly linked to the consumption of cereal grains, sweet food and carbonated beverages $(p<.05)$. Especially a strong relationship was observed between perceived stress and the consumption of sweet 


\begin{tabular}{|c|c|c|c|c|c|}
\hline \multirow{3}{*}{\multicolumn{2}{|c|}{$\begin{array}{l}\text { Table 2. Interrelationship between } \\
\text { nutrition habits and perceived } \\
\text { stress among students }\end{array}$}} & \multicolumn{4}{|c|}{ Stress } \\
\hline & & \multicolumn{2}{|c|}{ Females } & \multicolumn{2}{|c|}{ Males } \\
\hline & & $\begin{array}{c}\text { Correlation } \\
\text { coefficient }\end{array}$ & $p$ value & $\begin{array}{c}\text { Correlation } \\
\text { coefficient }\end{array}$ & $p$ value \\
\hline & Breakfast consumption & .143 & .183 & -.150 & .225 \\
\hline & Mealtime & .099 & .359 & .047 & .706 \\
\hline & Meat & .029 & .787 & -.089 & .472 \\
\hline & Fish & -.125 & .245 & -.103 & .409 \\
\hline & Dairy products & -.114 & .289 & -.020 & .875 \\
\hline & Cereal grains & $.213 *$ & .046 & -.067 & .594 \\
\hline & Fruit and vegetables & -.169 & .116 & -.139 & .263 \\
\hline & Sweet food & $.386 * *$ & .001 & .089 & .474 \\
\hline Notes. ${ }^{*} p<.05, * * p<.01$ & Carbonated beverages & $-.265 *$ & .013 & .012 & .921 \\
\hline
\end{tabular}

Table 3. Interrelationship between harmful habits and perceived stress among students

Note. $* * p<.01$

\begin{tabular}{|c|c|c|c|c|}
\hline \multirow{2}{*}{} & \multicolumn{4}{|c|}{ Stress } \\
\cline { 2 - 5 } & \multicolumn{2}{|c|}{ Females } & \multicolumn{2}{c|}{ Males } \\
\cline { 2 - 5 } & $\begin{array}{c}\text { Correlation } \\
\text { coefficient }\end{array}$ & $p$ value & $\begin{array}{c}\text { Correlation } \\
\text { coefficient }\end{array}$ & $p$ value \\
\hline Smoking & -.070 & .516 &. $.446 * *$ & .001 \\
\hline Alcohol consumption & .039 & .721 & .009 & .944 \\
\hline
\end{tabular}

foods ( $p=.001)$. It is necessary to mention that these interrelationships were determined only among females, while among males statistically significant relationship was not found $(p>.05)$. The analysis of the association between breakfast consumption, mealtime and perceived stress among students revealed that having breakfast and mealtime were not statistically significantly related to perceived stress $(p>.05)$. Therefore, breakfast consumption and mealtime did not have a significant effect on perceived stress among students.

In order to find out the interrelationship between perceived stress and harmful habits, such as smoking and alcohol consumption (Table 3), it was determined that smoking was significantly related to perceived stress among students $(p<.05)$. We hypothesized that stress was perceived more frequently by students who were smoking regularly. It is important to highlight that a strong interrelationship was observed only among males. The statistically significant relationship between stress and smoking among females was not found $(p>.05)$. The analysis of the association between perceived stress and alcohol consumption among students did not show statistically significant interrelationship $(p>.05)$. Thus, alcohol consumption is supposed not to be associated with perceived stress.

\section{DISCUSSION}

During studies students spend much time sitting and mentally working, therefore physical activity and exercises are very important (Strazdienè \& Adaškevičienè, 2012). The results of the study showed that the majority of students of the Lithuanian Sports University were sufficiently physically active. Moderate and high level of physical activity were determined in $81.8 \%$, and $2.3 \%$ of females, and in males $-65.7 \%$ and $14.9 \%$, respectively. According to the data of the study, $15.9 \%$ of females and $19.4 \%$ of males were insufficiently physically active. The similar results were found by Česnavičienè, Proškuvienè, and Motiejūnaitė (2015). According to the authors, 
insufficient physical activity was determined in $19.2 \%$ of females and $9.9 \%$ of males. A comparison of our data with studies performed by foreign researchers revealed a similar trend - the majority of students showed a moderate and high level of physical activity, and only a small part of students was insufficiently physically active (Bergier et al., 2017; Malmborg, Bremander, Olsson, \& Bergman, 2017; Niedermeier, Frühauf, Kopp-Wilfling, Rumpold, \& Kopp, 2018).

According to the World Health Organization recommendations (WHO, 2018), proper nutrition should include a large amount of fruit, vegetables and whole cereal grains, as well as a low consumption of saturated fats, salt, and refined carbohydrates. However, the data of our study revealed that nutrition was not well balanced among students. The analysis of the data showed that the majority of females $(83.0 \%)$ and males $(80.6 \%)$ consumed fruit and vegetables occasionally, and only $8.0 \%$ of females and $4.5 \%$ of males reported having fruit and vegetables 5-7 times per week. Insufficient intake of fresh vegetables was also determined by Lithuanian authors Samsonienė and Zimnicka (2013). According to these authors, only $14.0 \%$ of females and males have daily intake of fresh vegetables. Our data showed that $44.3 \%$ of females and $67.2 \%$ of males consumed meat frequently $-5-7$ times per week. The results of the study performed by Yahia, Wang, Rapley, and Dey (2016) also revealed a higher frequency of meat consumption among males. According to their data, daily consumption of meat was pointed out by $35.0 \%$ of males and $24.0 \%$ of females. The analysis of our results determined the frequent sweet food consumption by $27.3 \%$ of females and $7.5 \%$ of males. According to the results of the study performed by Senikiene, Lukoševičius, Jurkštienè, Šimonienè-Kazlauskienė, and Gintilienė (2016), even $75.0 \%$ of all interviewed students had daily consumption of sweet foods. According to our data, females statistically significantly more frequently used sweets, compared with males $(p<.05)$. This trend among genders has also been observed in the studies carried out by other researchers (El Ansari \& Berg-Beckhoff, 2015; Yahia et al., 2016; Kardelis $\&$ Kardelienè, 2013). Similar differences in nutrition habits among genders were determined by German researchers Hilger, Loerbroks, and Diehl (2017). According to the authors, females were more likely to use fruit, vegetables, and sweets more frequently, while males tended to choose fish, meat, and their products.

A balanced diet should provide a daily ration of sufficient number of calories during breakfast and dinner (Česnavičienè et al., 2015). The analysis of our study showed that the majority of students (88.6\% of females and $73.1 \%$ of males) were eating breakfast. A similar tendency was also determined in studies of other researchers. Hilger et al. (2017) found that breakfast eating on a regular basis was reported by $74.3 \%$ of respondents. According to the study performed by Yahia et al. (2016), breakfast consumption was pointed out by a smaller number of students $-58.0 \%$ of females and $41.0 \%$ of males. Strukčinskienè, Griškonis, and Strukčinskaitė (2013) determined that $57.3 \%$ of students had daily breakfast.

The analysis of smoking habits among students have revealed that $14.8 \%$ of females and $19.4 \%$ of males smoked on a daily basis. In their study, Papier, Ahmed, Lee, \& Wiseman (2015) found a smaller number of students who smoked on a daily basis compared to our respondents, i.e. $6.9 \%$ of students (8.5\% of males and $5.5 \%$ of females) smoked on a daily basis. Samsonienè and Zimnicka (2013) determined that $14.4 \%$ of males and $7.7 \%$ of females smoked on a daily basis. However, the results in the Tarejeva et al. (2015) study showed that a daily use of tobacco products was frequent among Vilnius University students: $39.5 \%$ of students smoked on a regular basis: $45 \%$ of males and $34.9 \%$ of females.

Excessive alcohol consumption among students of higher education institutions is a common problem in our society (Nasui, Popa, \& Popescu, 2016). The analysis of alcohol consumption habits among students showed that wine was used 2-3 times per month by $33.0 \%$ of females and $11.9 \%$ of males, however, $23.9 \%$ of males consumed beer more frequently - 2-3 times per week compared to females $(5.7 \%)$. According to Indrašiene et al. (2017), wine and champagne are most commonly consumed alcohol beverages. According to the data of the study performed by Tarejeva et al. (2015), $21.6 \%$ of males and $13.0 \%$ of females had intake of alcohol beverages a few times per week. It was determined that mostly students (37.85 of males and $40.0 \%$ of females) consumed alcohol beverages once per week.

Physical activity has been proven to promote positive changes in mental health including coping with stress (Salmon, 2001). Our analysis of the data 
showed that physical activity in the sample of the studied was inversely related to perceived stress $(p<.05)$. Therefore, physically active students were less vulnerable to the effects of stress. This conclusion has also been confirmed by the study performed by Meyer and Larson (2018), according to which a statistically significant inverse relationship between physical activity frequency and perceived stress among students was found $(p<.05)$.

The analysis of the associations between nutrition habits and perceived stress among students determined a statistically significant relationship between perceived stress and cereal grains, and the consumption of sweets; negative relationship was found between stress and intake of carbonated beverages in the sample of females $(p<.05)$. Statistically significant relationship between perceived stress and nutrition habits among males was not found $(p>.05)$. Foreign researchers (El Ansari, Adetunji, \& Oskrochi, 2014) revealed a negative interrelationship between healthy foods and stress among students. The consumption of fresh fruit and vegetables has been proven to be negatively linked to a subjective perception of stress among students. According to the results of the research performed by El Ansari et al. (2014) and our study, statistically significant associations between perceived stress and the consumption of dairy, meat and fish products are not present. Both studies have revealed statistically significant relationship between stress and cereal grains, and sweets in the sample of females. The results of the research carried out by El Ansari and Berg-Beckhoff (2015) and our study have shown negative statistically significant interrelationship between carbonated beverages and stress in the group of females.

Although our study did not find statistically significant relationship between stress and breakfast eating ( $p>.05)$, foreign researchers Richards and Smith (2016) determined that breakfast skipping was statistically significantly linked to a higher level of perceived stress, anxiety, and depression among students $(p<.05)$. According to Pelletier, Lytle, and Laska (2016), breakfast and supper were associated with perceived stress among students with normal body weight, while dinner skipping was statistically significantly related to a higher level of stress among students with normal body weight and obesity. Despite these findings, there are also studies confirming our conclusions, namely, breakfast skipping is not linked to perceived stress (Lovell, Nash, Sharman, \& Lane, 2015).

In our study, the analysis of the associations between stress and smoking among students showed that stress was statistically significant related to smoking only in the sample of males ( $p<$ .05). According to Pelletier et al. (2016), smokers have experienced a higher level of stress than nonsmokers. Researchers Galéra et al. (2017) also determined statistically significant relationship between students who perceived a high level of stress and the number of cigarettes smoked $(p<$ .05). AlSwuailem, AlShehri, and Al-Sadhan (2014) found that the majority of students who smoked on a regular basis (47.8\%) reported smoking as the primary reason for managing stress.

The analysis of the interrelationships between alcohol consumption and perceived stress in our study determined that both these variables were not associated in the groups of females and males $(p>.05)$. Although a number of studies have shown that students who perceived a higher level of stress are more likely to consume alcohol beverages (Chen \& Feeley, 2015; Demirbaş, İlhan, Yildırım, \& Doğan, 2016; Jang, Sohn, \& Yu, 2018; Tavolacci et al., 2016), Lovell et al. (2015) determined that intake of alcohol was not related to stress, anxiety or depression in the samples of females and males $(p>.05)$. The results of the other researchers Papier et al. (2015) revealed that the associations between alcohol consumption and stress had significant effects only in males $(p<.05)$.

\section{CONCLUSIONS}

1. The majority of students are sufficiently physically active. Insufficient level of physical activity was found in $15.9 \%$ of females and $19.4 \%$ of males. A significant difference of physical activity was determined between genders - females were physically more active than males.

2. Females and males demonstrated different nutrition habits. Females more frequently had breakfast, consumed sweets. Males more frequently consumed meat. Regular breakfast consumption was reported by $88.6 \%$ of females and $73.1 \%$ of males.

3. The study determined that males more frequently consumed beer, while females prefered wine to beer. Daily smoking was reported by $14.8 \%$ 
of females and $19.4 \%$ of males, however, a significant difference between genders was not found.

4. A significant relationship between perceived stress and physical activity was found among students. Perceived stress among females was associated with the consumption of cereal grains, sweets and carbonated beverages, while a strong relationship between smoking and stress was observed in the sample of males.

\section{REFERENCES}

AlSwuailem, A. S., AlShehri, M. K., \& Al-Sadhan, S. (2014). Smoking among dental students at King Saud University: Consumption patterns and risk factors. The Saudi Dental Journal, 26(3), 88-95. doi: 10.1016/j. sdentj.2014.03.003

Arora, A., Kannan, S., Gowri, S., Choudhary, S., Sudarasanan, S., \& Khosla, P. P. (2016). Substance abuse amongst the medical graduate students in a developing country. The Indian Journal of Medical Research, 143(1), 101-103. doi: 10.4103/0971-5916.178617

Bergier, J., Bergier, B., \& Tsos, A. (2017). Variations in physical activity of male and female students from the Ukraine in health-promoting life style. Annals of Agricultural and Environmental Medicine, 24(2), 217221. doi: 10.5604/12321966.1230674

Bolotin, A. \& Bakayev, V. (2015). Structure and content of the educational technology of managing students' healthy lifestyle. Journal of Physical Education and Sport, 15(3), 362-364. doi: 10.7752/jpes.2015.03054

Brown, O. N., O’Connor, L. E., \& Savaiano, D. (2014). Mobile MyPlate: A pilot study using text messaging to provide nutrition education and promote better dietary choices in college students. Journal of American College Health, 62(5), 320-327. doi: 10.1080/07448481.2014.899233

Chen, Y., \& Feeley, T. H. (2015). Predicting binge drinking in college students: Rational beliefs, stress, or loneliness? Journal of Drug Education, 45(3-4), 133155. doi: 10.1177/0047237916639812

Česnavičienè, J., Proškuvienė, R., \& Motiejūnaitė, R. (2015). Lietuvos edukologijos universiteto studentuc fizinio aktyvumo ir mitybos ịpročių sąsajos. Sporto mokslas, 3(81), 37-45. doi: 10.15823/sm.2015.17

Demirbaş, H., İlhan, I. Ö., Yıldırım, A., \& Doğan, I. B. (2016). Psychological factors related with substance use among regularly drinking university students with low income. Egitim ve Bilim, 41(183), 101-109. doi: 10.15390/EB.2016.1370

El Ansari, W., Adetunji, H., \& Oskrochi, R. (2014). Food and mental health: Relationship between food and perceived stress and depressive symptoms among university students in the United Kingdom. Central European Journal of Public Health, 22(2), 90-97. doi: 10.21101/cejph.a3941

El Ansari, W., \& Berg-Beckhoff, G. (2015). Nutritional correlates of perceived stress among university students in Egypt. International Journal of Environmental Research and Public Health, 12(11), 14164-14176. doi: 10.3390/ijerph121114164
Galéra, C., Salla, J., Montagni, I., Hanne-Poujade, S., Salamon, R., Grondin, O., ... \& Michel, G. (2017). Stress, attention deficit hyperactivity disorder (ADHD) symptoms and tobacco smoking: The i-Share study. European Psychiatry, 45, 221-226. doi: 10.1016/j. eurpsy.2017.07.007

Grabauskas, V. J., Zaborskis, A., Klumbienè, J., Petkevičienè, J., \& Žemaitienè, N. (2004). Lietuvos paauglių ir suaugusių žmonių gyvensenos pokyčiai 1994-2002 metais. Medicina, 40(9), 884-890.

Hilger, J., Loerbroks, A., \& Diehl, K. (2017). Eating behaviour of university students in Germany: Dietary intake, barriers to healthy eating and changes in eating behaviour since the time of matriculation. Appetite, 109, 100-107. doi: 10.1016/j.appet.2016.11.016

Indrašienè, V., Jegelevičienè, V., Merfeldaitė, O., Railienè, A., \& Žemaitaitytė, I. (2017). Alkoholio, tabako ir kitų psichiką veikiančių medžiagų paplitimas tarp Lietuvos aukštujjų mokyklų studentų. Socialinis darbas, 15(2), 86-100. doi: 10.13165/SD-17-15-2-05

Jang, S. M., Sohn, S., \& Yu, M. (2018). Perceived stress, alcohol consumption, and Internet use among Korean college students: Does sensation-seeking matter? Children and Youth Services Review, 88, 354360. doi: 10.1016/j.childyouth.2018.01.038

Kardelis, K., \& Kardelienè, L. (2013). Pirmo kurso studentų fizinè gerovè: sąsaja tarp fizinio aktyvumo ir mitybos. Studijos šiuolaikineje visuomenejje, 4(1), 172177.

Konduri, N., Gupchup, G. V., Borrego, M. E., \& Worley-Louis, M. (2006). Assessment of the reliability and validity of a stress questionnaire for pharmacy administration graduate students. College Student Journal, 40(1), 78-91.

Lin, S. H., \& Huang, Y. C. (2014). Life stress and academic burnout. Active Learning in Higher Education, 15(1), 77-90. doi: 10.1177/1469787413514651

Lovell, G. P., Nash, K., Sharman, R., \& Lane, B. R. (2015). A cross-sectional investigation of depressive, anxiety, and stress symptoms and health-behavior participation in Australian university students. Nursing \& Health Sciences, 17(1), 134-142. doi: 10.1111/ nhs. 12147

Malmborg, J., Bremander, A., Olsson, M. C., \& Bergman, S. (2017). Health status, physical activity, and orthorexia nervosa: A comparison between exercise science students and business students. Appetite, 109, 137-143. doi: 10.1016/j.appet.2016.11.028 
Melaku, L., Mossie, A., \& Negash, A. (2015). Stress among medical students and its association with substance use and academic performance. Journal of Biomedical Education, 1-9. doi: 10.1155/2015/149509

Merkys, G., Norkus, A., \& Dovydaitis, J. (2016). Lietuvos studentų mitybos ipročiai ir juos sąlygojantys veiksniai: masinès apklausos rezultatai. Sveikatos mokslai, 26(6), 5-12. doi: 10.5200/sm-hs.2016.084

Meyer, S., \& Larson, M. (2018). Physical Activity, Stress, and Academic Performance in College: Does Exposure to Stress Reduction Information Make a Difference? College Student Journal, 52(4), 452-457.

Nasui, B. A., Popa, M., \& Popescu, C. A. (2016). Drinking patterns and behavioral consequences: A cross-sectional study among Romanian university students. Slovenian Journal of Public Health, 55(1), 59-66. doi: 10.1515/ sjph-2016-0009

Niedermeier, M., Frühauf, A., Kopp-Wilfling, P., Rumpold, G., \& Kopp, M. (2018). Alcohol Consumption and Physical Activity in Austrian College Students: A Cross-Sectional Study. Substance Use \& Misuse, 53(10), 1581-1590. doi: 10.1080/10826084.2017.1416406

Papier, K., Ahmed, F., Lee, P., \& Wiseman, J. (2015). Stress and dietary behaviour among first-year university students in Australia: Sex differences. Nutrition, 31(2), 324-330

Pelletier, J. E., Lytle, L. A., \& Laska, M. N. (2016). Stress, health risk behaviors, and weight status among community college students. Health Education \& Behavior, 43(2), 139-144. doi: 10.1177/1090198115598983

Plotnikoff, R. C., Costigan, S. A., Williams, R. L., Hutchesson, M. J., Kennedy, S. G., Robards, S. L., ... \& Germov, J. (2015). Effectiveness of interventions targeting physical activity, nutrition and healthy weight for university and college students: A systematic review and meta-analysis. International Journal of Behavioral Nutrition and Physical Activity, 12(1), 45. doi: 10.1186/ s12966-015-0203-7

Proškuvienè, R., \& Česnavičienė, J. (2015). Pedagogines studijas pasirinkusių jaunuolių mitybos ypatumai. Visuomenès sveikata, 1(68), 68-77.

Richards, G., \& Smith, A. P. (2016). Breakfast and energy drink consumption in secondary school children: Breakfast omission, in isolation or in combination with frequent energy drink use, is associated with stress, anxiety, and depression cross-sectionally, but not at 6-month follow-up. Frontiers in Psychology, 7(106), 1-10. doi: 10.3389/fpsyg.2016.00106

Rosiek, A., Rosiek-Kryszewska, A., Leksowski, Ł., \& Leksowski, K. (2016). Chronic stress and suicidal thinking among medical students. International Journal of Environmental Research and Public Health, 13(2), 212-228. doi: 10.3390/ijerph13020212
Salmon, P. (2001). Effects of physical exercise on anxiety, depression, and sensitivity to stress: A unifying theory. Clinical Psychology Review, 21(1), 33-61.

Samsonienè, L., \& Zimnicka, V. (2013). Studentų mitybos ipročiai. Sveikatos mokslai, 23(1), 109-113. doi: 10.5200/sm-hs.2013.020

Senikienè, Ž., Lukoševičius, A., Jurkštienè, V., Šimonienè-Kazlauskienè, G., \& Gintilienė, M. (2016). Studentų mitybos ịpročių analizè. Sveikatos mokslai, 26(6), 65-71. doi: 10.5200/sm-hs.2016.093

Shamsuddin, K., Fadzil, F., Ismail, W. S. W., Shah, S. A., Omar, K., Muhammad, N. A., ... \& Mahadevan, R. (2013). Correlates of depression, anxiety and stress among Malaysian university students. Asian Journal of Psychiatry, 6(4), 318-323. doi:10.1016/j. ajp.2013.01.014

Stoliker, B. E., \& Lafreniere, K. D. (2015). The influence of perceived stress, loneliness, and learning burnout on university students' educational experience. College Student Journal, 49(1), 146-160.

Strazdienè, N., \& Adaškevičienè, E. (2012). Studentų sveikatą stiprinantis fizinis aktyvumas, jo raiška laisvalaikiu. Tiltai, 61(4), 93-104.

Strukčinskienė, B., Griškonis, S., \& Strukčinskaite, V. (2013). Vakarų Lietuvos jaunimo gyvensenos ypatumai. Sveikatos mokslai, 23(1), 21-25. doi: 10.5200/smhs.2013.003

Tarejeva, J., Žagminas, K., \& Serapinas, D. (2015). Vilniaus universiteto studentų rizikingos elgsenos ịvertinimas. Sveikatos mokslai, 25(6), 51-55. doi: 10.5200/smhs. 2015.116

Tavolacci, M. P., Boerg, E., Richard, L., Meyrignac, G., Dechelotte, P., \& Ladner, J. (2016). Prevalence of binge drinking and associated behaviours among 3286 college students in France. BMC Public Health, 16(1), 178. doi: 10.1186/s12889-016-2863-x

VanKim, N. A., \& Nelson, T. F. (2013). Vigorous physical activity, mental health, perceived stress, and socializing among college students. American Journal of Health Promotion, 28(1), 7-15. doi: 10.4278/ajhp.111101QUAN-395

World Health Organisation. (2018). Healthy diet. https:// www.who.int/en/news-room/fact-sheets/detail/healthydiet

Yahia, N., Wang, D., Rapley, M., \& Dey, R. (2016). Assessment of weight status, dietary habits and beliefs, physical activity, and nutritional knowledge among university students. Perspectives in Public Health, 136(4), 231-244. doi: 10.1177/1757913915609945

Žandaras, Ž., \& Stukas, R. (2015). Sveikatai nepalankių maisto produktų ir gérimų vartojimo paplitimas tarp Vilniaus universiteto studentų. Visuomenès sveikata, 2(69), 81-85. 